\title{
Active Learning in Teaching English for Young Learners
}

\author{
Amira Deani ${ }^{1}$, Pratomo Widodo ${ }^{2}$ \\ \{amiradeani97@gmail.com ${ }^{1}$, pratomo@uny.ac.id ${ }^{2}$ \} \\ Yogyakarta State University, Indonesia
}

\begin{abstract}
The goal of this study is to find out whether or not there is a significant impact of Active Learning Strategy on the young learners' learning outcomes in English and how the students' and teacher's perceptions on applying Active Learning in English class are. The study design is mixed study with one group pre-test and post-test design and structured interview. The sample consisted of the primary 3 students and the English teacher selected using the cluster random sampling technique. The result indicated that the post-test mean score (75.3962) was higher than the pre-test mean score (70.8524). The t-test value (10.272) was higher than the t-table (2.0860) at 5\% of the significance level and the t-Table at $1 \%$ of the significance level. The alternative hypothesis $(\mathrm{Ha})$ was then accepted and the null hypothesis $(\mathrm{Ho})$ was rejected. It could be concluded that there is a significant impact of Active Learning Strategy on the students' learning outcomes in English. Furthermore, the structured interview showed that Active learning gives positive impact in the teaching and learning process. However, the teacher also encounters some challenges in conducting active learning in the matter of lesson plan, teaching aids and time allocation.
\end{abstract}

Keywords: Active Learning, English, Young Learners

\section{Introduction}

English becomes the common language of international communication in the era of globalization[1]. One of the world's most popular languages is English, as it is a core means of communication in technology, business, information, culture and entertainment. That's why, it's necessary to help the students to acquire English and get a long-life learning in order to help them survive in this globalization era. Kids are special social beings with their own way of doing things [2]. In order to survive in the globalization era, children must get exposure consisting new learning experiences, new information to draw from, new skills to be mastered, new facts to be taught, new feelings to be felt, new ideas to be discussed, new problems to think about and new ways to understand. To master these challenges, a teacher must design a lesson plan which provides students the learning strategy where the students learn by listening, behaving, responding, reflecting and communicating with others through the process that teachers direct and encourage.

These ideas are suitable with Active Learning. Active Learning is the mechanism by which students participate in certain activities that encourage them to think about concepts and how they use certain ideas[3]. In addition, active learning defines any teaching strategy that incorporates students through important and thought-provoking exercises in the learning process[4]. While conducting active learning, students are required to assess their previous experience and skills to handle concepts or problems in particular discipline on a regular basis. Furthermore, active learning puts the student at the forefront of the learning process. The teacher offers opportunities for students to learn independently and trains students in the skills they need to successfully do so. In short, active learning is designed to provide students meaningful learning activities and triggers the students to think about the action that they do. The 
characteristic of active learning is to place learning as the core of education and to provide children with a children friendly platform in order to continually explore the world around them[5]. Moreover, active learning offers a series of activities in which students participate in the course actively, including problem solving and critical thinking, in order to help them learn the material and accomplish the learning objective. Most strategies consist of a lecture, followed by activities that serve to clarify and improve what the student has learned. This was usually done just after the lecture while students are still in the classroom[6]. Examples of active learning activities are think-pair-share, treasure hunt, debate, questioning, group discussion, surveying, role-playing, teach ok, etc[7].

English teaching and learning has been considered for a long time as an important aspect of in Indonesia educational system[8]. In Indonesia English is taught and studied more commonly as a foreign language. This means the students barely get English exposure in their daily communication, they primarily learn English only at schools. English students in Indonesia cannot yet use English as a communication tool outside the classroom during their daily lives. According to Shearin in Sulistiyo, a language that is only studied through formal education is called a foreign language[9]. English teaching in Indonesia therefore presents a challenge which are not faced in countries such as Singapore, Malaysia, Netherland etc. that use English more often daily.

A number of factors create difficulties in Indonesia for EFL teaching[9]. First of all, not all students are encouraged to learn English. In the Indonesian curriculum, English is a required subject, meaning that students have to learn the language for tests, but their exposure to English lasts for only two hours a week. Students ' low motivation and the minimum amount of English learning time are obstacles not just for teachers but also for students. Next, the emphasis of English teaching is mainly on reading ability in school and university. The emphasis on teaching is on the premise that students can properly understand the structure and vocabulary of an English text. One effect of this is that other skills like speaking, writing and listening are largely overlooked[10]. English is one of the compulsory subjects taught in primary, secondary and tertiary Indonesian schools. In these schools, teaching and learning tasks primarily include learning vocabulary, grammar and reading English texts. Instead of using English for communication, it tends to focus on learning English norms of language[11].

Given that English is learned and taught primarily as a foreign language in schools in Indonesia, the role of teachers is especially important because they are the main source and facilitator of the knowledge and skills of this language. An English teacher shall play two roles simultaneously. First, the teachers must teach English and then create the course as exciting as possible to engage the students[12]. Students have limited access to the use of English in an EFL setting, and the classroom is typically the only place where they can use English. Guidance and clarification from teachers may also be the only way students can learn the language for communication [13].

Teachers are responsible for providing children with the best possible world and for giving children the chances to completely understand their cultures, inspiring them to one day strive for the return of the world to them as they move forward[14]. Nevertheless, teachers must also ensure that our young learners' creative spirit and many essential works and attributes that the teachers usually combine with the learners never fail to give us strength. Vygotsky's point of view also supports this argument as he states that children attempting to do stuff and capable of thinking are both supported by engaging with an adult. Vygotsky considered the child to be the first to do something in society, to help others in various ways and to progressively shift from reliance on others to independent thought and action [15]. 
In addition, Cameron states that Piaget has a point of view that said that the a kid is an active learner. Therefore, Piaget's is interested in how young children act and influence their mental development in the world around them. The child is seen to interact continuously with the world around him/her, and to solve the problems presented by the environment. It is through experience that learning comes about to solve problems. Children also seek the motivations and implications of what they see others do, applying their awareness and experience to their attempts to make sense of others' behaviour and words[15]. Next, young children are now considered competent, active agents of intellectual development of their own. In brief, the imagination of the young child has come to life[16]. It can be concluded, on the basis of the hypotheses discussed above, that the emphasis is placed on the importance of children as active learners who can set, plan and revise goals. Children are considered to be students who collect and arrange material. Cognitive development involves the formation of formal understanding structures including biological concepts, early numerical sense and early basic physics knowledge. In addition, cognitive development also requires the incremental development of memory, understanding, and strategies for problem solving. Children often strive to make sense of what adults tell them and order them to do, for example, seeking and creating a meaning and intention. Children can only make sense with respect to their minimal and partial awareness of the universe. In order to decide whether pupils will understand what to do or will make sense of a new language, teachers must also evaluate classroom interactions from the point of view of the students.

That's why active learning is suggested in this paper. Active learning is a learning process in which all students work together in the classroom to acquire knowledge of truth, ideas and skills through teacher-led assignments and activities relevant to the course materials [17]. Actually, active learning is also described as a learning process that encourages the students to be active during instructional process so they can understand the materials easier.

Bonwell and Eison note that students are engaged in the process in active learning, and that they engage when they do something other than passive listening [18]. So active learning is more likely to take place as students are doing something other than just listen everything what the teachers say. Therefore, active learning might take the form of a learning strategy in which learners are actively or experientially engaged in the learning process and where, depending on student participation, various levels of active learning occur. [18]. It can be recognized that students are expected to use content knowledge, not simply gain it in active learning. [19].

Moreover, Benjamin refers to the concept of active learning, which is: in the classroom, students do more than just listen, Less emphasis is placed on information transfer and more on improving students' skills, students use higher-level thought (analysis, synthesis, evaluation), students participate in other tasks (e.g. reading, writing), and the discovery of students' own attitude[20]. In addition, Douglas Barnes has proven the fundamental concepts of active learning[21]: Purposive, which means the relevance of the work to the needs of the students, Reflective which is the reflection by students on the nature of what is learnt, Negotiated meaning Negotiation of learning objectives and methods between students and teachers, Critical where students appreciate and study the different ways and means to learn the material, Complex that means Students equate learning activities with real-life problems, and evaluate reflectively, Situation-driven and Engaged where real life tasks are expressed in the activities carried out.

Mckinney states that within language classrooms there are many kinds of active learning methods such as, mind mapping, composing a newsletters, creating a journal, analysing case studies that is related to the materials, conducting a mini research, debate, analysing a video, games, enabling cooperative learning and collaborative learning[22]. 
Those methods can be adjusted in the class according to the students' needs, class proportion and the materials that are learnt

For years, educators, researchers, and policymakers have debated whether active learning is an effective way to teach young children in many disciplines, including English. Active learning has caused a paradigm shift from conventional teachers focused on teaching methods to a more inclusive, child-friendly student-centered learning strategy that aims to inspire, improve, shape and reward them (children) as active learners through an engaging process based on their ability to observe, explore, listen, understand, ask and ' find out ' support in creating competent skills and potentially productive workforce to meet 21 st century gruesome demands[23].

Taking into account the above explanation, the present paper aims to answer these study questions:

1. Is there a significant effect of Active Learning Strategy on the students' learning outcomes in English?

2. How are the students' and teacher's perceptions on applying Active Learning in English class?

\section{Methods}

The type of the study was mixed study (quantitative and qualitative). The quantitative study was conducted by using one group pre- test and post-test design to see the significant effect of Active Learning Strategy on the students' learning outcomes in English. The design of the quantitative study is described as follows[24]:

\begin{tabular}{llll} 
Group & Pre-test & Treatment & Post-test \\
\hline Experimental & O1 & $\mathrm{X}$ & $\mathrm{O} 2$ \\
$\mathrm{O} 1$ & : Pre-test of experimental group & & \\
$\mathrm{X}$ & $:$ Treatment & & \\
$\mathrm{O} 2$ & : Post-test of experimental group & &
\end{tabular}

The participants of this study are a total of 21 third-graders aged 8 on average in an private primary school in Pekanbaru, Riau. Participants are English as a foreign language learner. The writer used cluster sampling methodology to only take one class as the sample to be observed. Gay and Mills states that random sampling is the method of selecting a sample so that every person has the same and independent probability of being chosen for the sample in a given population. In cluster random sampling, groups are randomly selected.

In doing this research, the students were given the pre-test and post-test. Pre-test was performed prior to treatment and post-test was performed after treatment. The T-test was used to analyze the data using SPSS version 23.0. The T-test was used to compare the pre-and posttest discrepancy effects.

Furthermore, the qualitative study was also conducted by doing a structured-interview with the teacher and the students to know the students' and teachers' perception about Active Leaning strategy. This qualitative study involved 1 English Teachers from the class where the writer took samples for the quantitative study, 2 high-performing and 2 low-performing students. They were chosen randomly as participants of this study. This small number of participants is considered sufficient for a small scale qualitative study as a qualitative study typically does not usually aim to address issues of representativeness, in qualitative study, the 
richness of the data is more important. In addition, the findings are not intended for generalization.

The questions that are given for the teachers are: (1) How do you define the Active Learning Strategy in the context of teaching English? (2) What kinds of benefits and problems do they encounter during the implementation of the strategy? Meanwhile, the question for the students is: How do you feel during the learning process?

\section{Findings and Discussion}

\section{Findings}

The result of the pre-test is presented in the following table:

Table 1. Descriptive Statistics of Pre-test Score

\begin{tabular}{lllllll} 
& N & Minimum & Maximum & Mean & $\begin{array}{l}\text { Std. } \\
\text { Deviation }\end{array}$ & $\begin{array}{l}\text { Std. Error } \\
\text { Mean }\end{array}$ \\
\hline $\begin{array}{l}\text { Pre-test } \\
\text { Score }\end{array}$ & 21 & 41.67 & 91.67 & 70.8524 & 14.91127 & 3.25391 \\
\hline
\end{tabular}

Table (1) shows that the mean of students' score was 70.8524. Meanwhile, the minimum score that students reached in pre-test was 41.67 and the maximum score was 91.67.

The result of the post-test is shown in the following table:

Table 2. Descriptive Statistics of Post-test

\begin{tabular}{lllllll}
\hline & N & Minimum & Maximum & Mean & $\begin{array}{l}\text { Std. } \\
\text { Deviation }\end{array}$ & $\begin{array}{l}\text { Std. Error } \\
\text { Mean }\end{array}$ \\
\hline $\begin{array}{l}\text { Pre-test } \\
\text { Score }\end{array}$ & 21 & 44.44 & 94.44 & 75.3962 & 14.22566 & 3.10429 \\
\hline
\end{tabular}

According to the table (2), the mean of students' score was 75.3962. Meanwhile, the minimum score which students got in post-test was 44.44 and the maximum score was 94.44 .

Table 3. Paired Samples Statistics

\begin{tabular}{lllll}
\hline & Mean & N & Std. Deviation & $\begin{array}{l}\text { Std. } \\
\text { Mean }\end{array}$ \\
\hline Pre-test & 70.8524 & 21 & 14.91127 & 3.25391 \\
Post-test & 75.3962 & 21 & 14.22566 & 3.10429 \\
\hline
\end{tabular}

Table (3) shows the total number of pre- and post-test students is 21 . Pre-test mean score is 70.8524 , and post-test mean score is 75.3962 . The difference of the mean score between pre-test and post-test is 4.5438

The final stage of analyzing the data was hypothesis testing. The t-test formula for 
comparing pre- and post- test results was used in this study to determine whether he hypothesis could be accepted, and whether the treatment could influence the learning outcome of the student in English.

Table 4. Paired Samples t-test

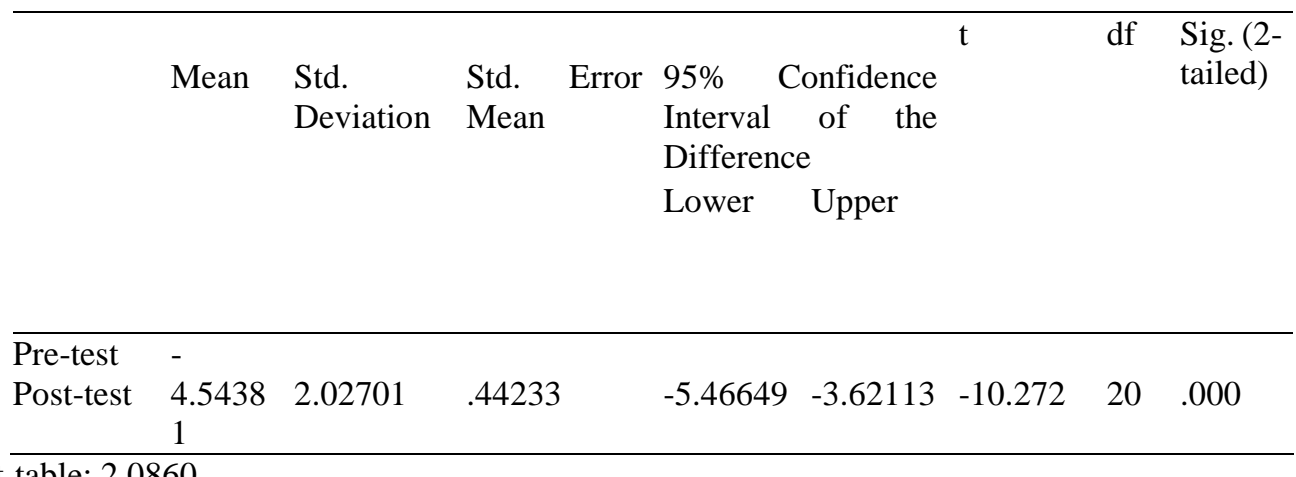

t-table: 2.0860

Finally, in order to prove the hypothesis, the data were computed with the following assumptions using t-test method:

1. If t-test $>\mathrm{t}$-table, the alternative hypothesis $(\mathrm{Ha})$ is accepted and the Null Hypothesis (Ho) is rejected.

2. If $\mathrm{t}$-test $<\mathrm{t}$-table, the alternative hypothesis $(\mathrm{Ha})$ is rejected and the Null hypothesis (Ho) is accepted.

Table 4 shows that the result of t-test is 10.272 . Meanwhile, t-table is 2.0860. It means that t-test has higher value than the t-table. Therefore, it can be concluded that Ha is accepted and Ho is rejected. It's proven that there is a significant effect of Active Learning Strategy on the students' learning outcomes in English

\section{Discussion}

It may be claimed, according to the description of the data, that the Active Learning Strategy is appropriate to teaching English in Primary 3 class. The results can be proven by comparing the student pre-test score and the student post-test score. The result shows that the student post-test score is higher than their pre-test score, which indicated an increase in the learning outcomes of students in English since using Active Learning.

Furthermore, the writer also did structured-interview with the teacher and the students. One of the questions asked during the interview with the teacher was 'How do you define the Active Learning Strategy in the context of teaching English?'. This question was intended to explore the basic understanding and perception of the teacher. The teacher's understanding and positive perception on the strategy would not only guide the teacher in applying the strategy but also could greatly influence the quality and efficacy of the teacher's way of teaching in the classroom.

Ms. E, the English teacher of Primary 3 class, points that active learning is a learning process that applies some stages in learning such as observing, finding information, associating, communicating, etc. Moreover, she mentioned that students are expected to be active in all 
activities since the teacher gives chances for them to be independent. The teacher must provide teaching aid that can support the learning activities and maintain the process to reach the learning objectives.

The next question is 'What kinds of benefits and problems do they encounter during the implementation of the strategy?' According to Ms. E, there are so many benefits of applying active learning but she also encountered some problems during the learning activity.

"In active learning, Students take full responsibility for their learning, take an active part in the lessons and understand more meaningfully what has been learnt."

That's the first thing that she mentioned about the benefit of Active Learning. Then she states that by doing active learning, students tend to ask questions and be curious about something they are learning so it can develop their critical thinking skills. Furthermore, students feel themselves learning, not only because they can find the information independently but also they can explore and solve a problem. In addition, students are engaged and competitive because the active learning invites them to DO something. In active learning, a teacher has a role as a facilitator who doesn't have to explain all things but the one who helps and supervises the students. Finally, the most important benefit and can be obtained by doing active learning is Long-life learning. The students tend to memorize the material well and the knowledge they get will stay longer in their cognitive area.

"Active learning strategy does not emphasize the provision of information, rather it enhances the skill and capacity of the students. This view is in accordance with the most dominant educational theorist who states that the object of education is to promote differences between individuals and to develop their independence in order to empower them to know each other. Active learning is then more modern and ideally suited to good and mediocre students in good classes. Students in active learning will develop strong thinking skills and, at the same time, become self-sufficient, learn to share their opinions among friends and come up with ideas to solve problems."

Ms. E adds that statement in the end of the interview It can be concluded that active learning has so many benefits in learning process. It helps students to gain the knowledge easier and the memories of the learning material will stay longer in their brain.

Yet, despite all of those benefits, Ms. E also states that active learning also has some flaws. In Active Learning, students have to be discipline with time allocation. If it is not planned, the learning objectives will not be reached as what's expected since the time is limited. Moreover, Ms. E states that

"In active learning, teachers will have to be well-prepared with teaching aids, lesson plan, and various activities. If the teachers are out of ideas, the active learning will be boring and you know what? Designing a good active learning lesson plans and teaching aids consume much time and kind of tiring.."

She further mentions that

"Active learning is a good strategy but I don't think it will be a good idea if you apply it in a big class with big amount of students because its hard to control the students and the time allocation."

It can be see clearly that Ms. E also encountered some problems while using Active learning especially in constructing the lesson plan and teaching aids. She also mentions that active learning isn't suitable for a class that has too many students because it's hard to control a lot of students by doing active learning. The class might be chaotic and the time allocation would be messed up.

After the writer was done doing the interview with the teacher, the writer continue to do the interview with 4 students. The question was the same for all of the students, it is 'How 
do you feel during the learning process?'

The students that were interviewed we J,K,M, and C. J and $\mathrm{K}$ are high performing students and $\mathrm{M}$ and $\mathrm{J}$ are low performing students.

"It's fun to learn English this way! This is the first time that I enjoy learning

English this much, I hope in the future will often use this method!'”

That's the first thing that came out of J's mouth when the writer asked the question. Moreover, she states that learning English by using active learning makes her doesn't feel sleepy at class and it feels like learning while playing. In the assessment, she can answer and remember the learning material easily.

After that, the writer asked $\mathrm{K}$, he states that "well, active learning is fun but hmm sometimes I just feel too tired to do the activities because it makes me move a lot in the class. I prefer to stick on my chair and do the activity there, I don't like to move a lot and sometimes if ms. E didn't give clear instruction, I got confused. But after all, it's not bad. It's fun as long as it's not too tiring or ms. E give a clear instruction and it helps me to memorize the learning material well."

According to $\mathrm{K}$, active learning is tiring because he doesn't like to move a lot but overall active learning still helps. $\mathrm{K}$ also states that it depends on how clear the instruction that is given by the teacher.

Next, the interview session was continued to $\mathrm{M}$.

"It's fuuun and the materials becomes easier. It's the first time that English become such an easy subject and it's the first time for me got 9 in the assessment. Ifeel happier studying English this way."

From what $\mathrm{M}$ said, it can be seen that Active Learning helps a lot in learning process. It makes the learning material is easier to understand. C's opinion is almost the same as M's opinion. $\mathrm{C}$ further mentions that Active learning does make him thinks harder but he enjoys the learning process. $\mathrm{C}$ is the last one that the writer interviewed.

\section{Conclusion}

This is a mixed study that aims at finding out whether or not there is a significant effect of Active Learning Strategy on the students' learning outcomes in English and How the students' and teacher's perceptions on applying Active Learning in English class are. Based on the result of the data analysis, it can be concluded that that there is a significant difference between the results of pre-test and post-test. Hence, it can be stated that the alternative hypothesis (Ha) is accepted and the null hypothesis (Ho) is rejected. In conclusion, this study has answered the study question namely that, there is a significant effect of Active Learning Strategy on the students' learning outcomes in English.

Furthermore, based on the interview that was conducted, it can be concluded that Active learning gives positive impact in the learning process. It helps students to think critically, memorize and understand the material easier. If the teacher can construct the lesson plan with good ideas, the class will be fun. Yet, the teacher also encounter some problems in applying active learning in the matter of lesson plan, teaching aids and time allocation.

\section{References}

[1] Wu TT, Huang YM. A mobile game-based English vocabulary practice system based on portfolio analysis. Journal of Educational Technology \& Society. 2017 Apr 1;20(2):265-77. 
[2] Octaviana DW. TEACHING ENGLISH TO YOUNG LEARNERS. ENGLISH EDUCATION: JOURNAL OF ENGLISH TEACHING AND RESEARCH. 2017 Oct 28;2(2):124-33.

[3] Edwards S. Active Learning in the Middle Grades: This Article Offers Examples of Developing Students' Participation as a Central Tenet of Ideal Middle Level Education That Is Intellectually Active, Socially Active, and Physically Active. Middle School Journal. 2015 May 1;46(5):26-32.

[4] Daniel T, Tivener K. Effects of sharing clickers in an active learning environment. Journal of Educational Technology \& Society. 2016 Jul 1;19(3):260-8.

[5] Singh N. Student-centered learning (SCL) in classrooms-A comprehensive overview. Educational Quest-An International Journal of Education and Applied Social Sciences. 2011;2(2):275-82.

[6] Gonzalez F. For some, active learning can be a nightmare. ASEE Prism. 2016 Dec 1;26(4):52.

[7] Jackson S. The challenge of active learning techniques in the distance learning classroom: avoiding the downward spiral of negative synergy. InEDULEARN10: International Conference on Education and New Learning Technologies 2010 (pp. 817-823).

[8] Mappiasse SS, Sihes AJ. Evaluation of English as a Foreign Language and Its Curriculum in Indonesia: A Review. English Language Teaching. 2014;7(10):113-22.

[9] Sulistiyo U. Learning English as A Foreign Language in An Indonesian University: A Study of NonEnglish Department Students' Preferred Activities Inside and Outside the Classroom. Indonesian Journal of English Teaching. 2016 Jul 13;5(1):1-26.

[10] Sugirin. Studying the academic reading comprehension process: Responding to methodological concerns. Paper presented to HERDSA Annual International Conference. Melbourne, 1999 Jul 1215 .

[11] Sawir E. Language difficulties of international students in Australia: The effects of prior learning experience. International Education Journal. 2005 Dec;6(5):567-80.

[12] Kassing RB. Perceptions of motivational teaching strategies in an EFL classroom: The case of a class in a private university in Indonesia. 2011

[13] Suryati N. Developing an effective classroom interaction framework to promote lower secondary school students' English communicative competence in Malang, East Java, Indonesia (Doctoral dissertation, University of Newcastle). 2013

[14] Caponegro RA. Recess!-exploring the cultures of childhood. The Looking Glass: New Perspectives on Children's Literature. 2007 Dec 4;11(2).

[15] Cameron L. Teaching Languages to Young Learners. United Kingdom: Cambridge University Press. 2001

[16] Bransford JD, Brown AL. How People Learn: Brain, Mind, Experience, and School: National Research Council. 1999. Retrieved from www.nap.edu/html/howpeople1/ch4.html

[17] Bell D, Kahrhoff J. Active Learning Handbook-Institute for Excellence in Teaching and Learning. Faculty Development Center, webster University. 2006.

[18] Bonwell CC, Eison JA. Active Learning: Creating Excitement in the Classroom. 1991 ASHE-ERIC Higher Education Reports. ERIC Clearinghouse on Higher Education, The George Washington University, One Dupont Circle, Suite 630, Washington, DC 20036-1183; 1991.

[19] Cameron BJ. Active Learning: Green Guide 2. Halifax, Nova Scotia, Society for Teaching and Learning in Higher Education. 1999.

[20] Benjamin Jr LT. Personalization and active learning in the large introductory psychology class. Teaching of Psychology. 1991 Apr 1;18(2):68-74. 
[21] Barnes DR. Active learning. Leeds University TVEI Support Project; 1989

[22] McKinney K, Heyl BS. Sociology through active learning: Student exercises. SAGE Publications; 2008 Jul 10

[23] Unicef. Child-friendly schools manual. http://www. unicef. org/publications/files/Chip_Friendly_Schools_Manual_EN_040809.pdf. 2009.

[24] Gay LR, Mills GE, Airasian PW. Educational research: Competencies for analysis and applications. Merrill/Pearson; 2009. 